\title{
Physiological and Biochemical Responses of Pearl Millet (Pennisetum glaucum L.) Seedlings Exposed to Silver Nitrate $\left(\mathrm{AgNO}_{3}\right)$ and Silver Nanoparticles (AgNPs)
}

\author{
Imran Khan ${ }^{1,+}$, Muhammad Ali Raza ${ }^{2,+}{ }^{\circ}$, Muhammad Hayder Bin Khalid ${ }^{3,+}$, \\ Samrah Afzal Awan ${ }^{4,+}$, Naveed Iqbal Raja ${ }^{4}$, Xinquan Zhang ${ }^{1}$, Sun Min ${ }^{1}$, Bing Chao Wu ${ }^{1}$, \\ Muhammad Jawad Hassan ${ }^{1}$ and Linkai Huang ${ }^{1, *(D)}$ \\ 1 Department of Grassland Science, Animal Science and Technology College, Sichuan Agricultural University, \\ Chengdu 611130, China \\ 2 College of Agronomy, Sichuan Agricultural University, Chengdu 611130, China \\ 3 Maize Research Institute, Sichuan Agricultural University, Chengdu 611130, China \\ 4 Department of Botany, PMAS-Arid Agriculture University, Rawalpindi 46000, Pakistan \\ * Correspondence: huanglinkai@sicau.edu.cn; Tel.: +86-187-83575058 \\ + These authors contributed equally to this work.
}

Received: 25 April 2019; Accepted: 24 June 2019; Published: 26 June 2019

\begin{abstract}
A rapid and continuous growth of silver nanoparticles (AgNPs) via their precursor "silver nitrate" $\left(\mathrm{AgNO}_{3}\right)$ has increased their environmental risk because of their unsafe discharge into the surrounding environment. Both have damaging effects on plants and induce oxidative stress. In the present study, differential responses in the morpho-physiological and biochemical profiles of P. glaucum (L.) seedlings exposed to various doses of $\mathrm{AgNPs}$ and $\mathrm{AgNO}_{3}$ were studied. Both have forms of Ag accelerated the reactive oxygen species (ROS) production, which adversely affected the membrane stability as a result of their enhanced accumulation, and resulted in a significant reduction in growth, that is, root length, shoot length, fresh and dry biomass, and relative water content. $\mathrm{AgNO}_{3}$ possessed a higher degree of toxicity owing to its higher accumulation than AgNPs, and induced changes in the antioxidants' enzyme activity: superoxide dismutase (SOD), peroxidase (POD), catalases (CAT), guaiacol peroxidase (GPX), ascorbate peroxidase (APX), and glutathione reductase (GR) activity, as well as proline content, total phenolic, and total flavonoids contents (TFCs) under all tested treatments $(\mathrm{mM})$. A decline in photosynthetic pigments such as total chlorophyll content and carotenoid content and alterations in quantum yield ( $\mathrm{Fv} / \mathrm{Fm})$, photochemical (qP), and non-photochemical quenching (NPQ) indicated the blockage of the electron transport chain (ETC), which led to a significant inhibition of photosynthesis. Interestingly, seedlings exposed to AgNPs showed less damaging effects on P. glaucum (L.) seedlings, resulting in relatively lower oxidative stress in contrast to $\mathrm{AgNO}_{3}$. Our results revealed that $\mathrm{AgNO}_{3}$ and $\mathrm{AgNPs}$ possessed differential phytotoxic effects on P. glaucum (L.) seedlings, including their mechanism of uptake, translocation, and action. The present findings may be useful in phytotoxic research to design strategies that minimize the adverse effects of AgNPs and $\mathrm{AgNO}_{3}$ on crops, especially in the agriculture sector.
\end{abstract}

Keywords: comprehensive; accumulation; antioxidants; photosynthesis; phytotoxic

\section{Introduction}

Pearl millet (P.glaucum L.) is one of the premium and important food crops that occupy the sixth rank in the world, with a huge cultivated area $(60 \%)$ in Africa and (35\%) in Asia. It covers about half 
of the total global production of millets and is utilized as a staple food, source of protein for human beings, and fodder for livestock [1,2]. Pearl millet grains are used to make flour, bread, pasture, and "coucous" [3]. As livestock fodder, it is mostly grown to produce hay, green-chop, silage, pasture, and stands over feed grazed directly $[4,5]$. The seedling stage of plants is very sensitive to different types of stresses, which leads to a great loss of crop production in agriculture system. Keeping in view the world human's population is prophesied to touch 9.6 billion by 2050, from today's total of about 7 billion [6], it will be the staple food for human beings in the coming years and extensively utilized by animals as feedstuff.

Nanotechnology is the science that relates to nanomaterials that possess molecular and atomic dimensions of less than a few nanometers. In recent years, most of the research work has been performed to explore the effects of nanoparticles (NPs) on plants, including other living organisms [7]. NPs are extensively being used in physics, chemistry, agricultural science, environmental science, and medicine [8], but their interactions with plant metabolism still needed more attention. Some different and contradictory assays have been reported on the applications of NPs with reference to absorption, uptake, accumulation, transformation, and their effects in fewer plant species [9]. After reduction, the ionic material from industrial discharge forms clusters and changes into nanoparticles, which may be taken up by plants through different ways [10]. Proper regulation and the safe discharge of industrial impurities into soil and water to control their adversative effect on plants requires further effort and investigation [11].

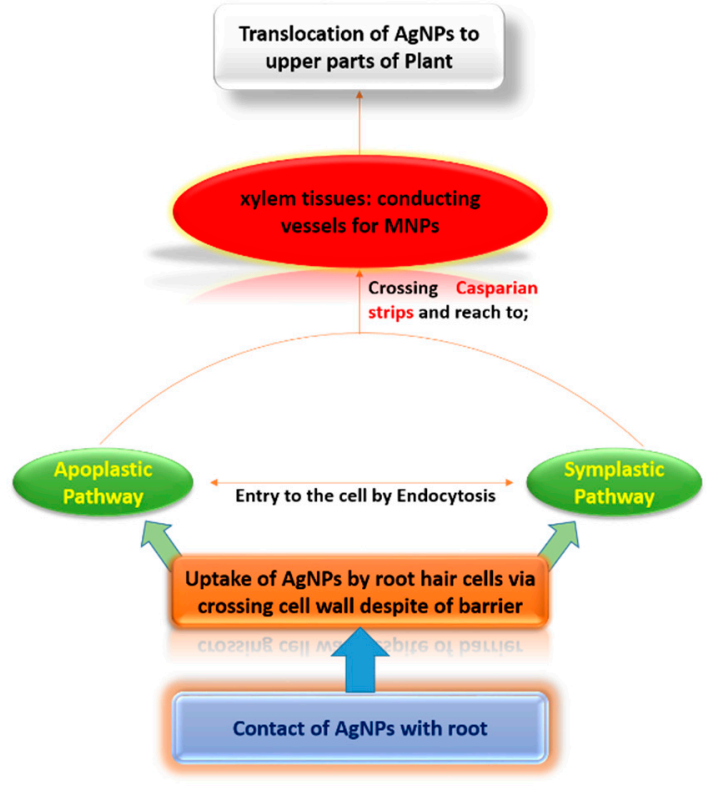

Figure 1. A possible mechanism of uptake and distribution of AgNPs in plants.

Various chemical compounds (chemical fertilizers and minerals) have been tested in agricultural systems to improve crop production, but unfortunately, they cause some serious health issues for human beings and side effects on plants, and harm the environment and soil in different ways. It has been found that less functional toxic elements in the biological systems make their way into the food chain, accumulate in plant tissues (Figure 1), and cause lethal effects to plant species [12]. In agriculture, metal-based NPs such as zinc $(\mathrm{Zn})$, silver $(\mathrm{Ag})$, copper $(\mathrm{Cu})$, iron $(\mathrm{Fe})$, and titanium dioxide $\left(\mathrm{TiO}_{2}\right)$ have been tested for crop improvement, but they induce more toxicity to crop plants. Among them, the interaction of AgNPs with plants is being tested on a large scale in the nano-research field [13]. Phytotoxic effects of AgNPs on plants depend upon the age and type of plant species, sizes and concentrations of nanoparticles, experimental conditions, and the duration of the experiment. Reported investigations have shown that AgNPs release $\mathrm{Ag}^{+}$into the surrounding environment, which leads to inhibition of respiratory enzymes and ultimately causes oxidative stress by producing reactive oxygen 
species (ROS) [14]. The main causes of toxic effects of AgNPs are still unclear, but may be caused by silver ions or their intrinsic properties. Existing literature on the phytotoxic effects of AgNPs is still limited and it is more important to explore their phytotoxic effects, as their productive and destructive effects on the environment are not fully known.

Moreover, it has been reported that as the concentration of AgNPs increases in plants, a reduction in root and shoot length and biomass strongly directs the toxicity to increase in plants [15]. The authors of [16] also reported that the interaction of NPs with plants had significant impacts on seed germination and seedling growth, and was dependent on the concentrations and properties of NPs and plant species. The accumulation of AgNPs in plant cells seems to be dependent on system reduction potential, and as such, NPs have both constructive and damaging impacts on the germination of seeds and root growth [17].

In addition, the phytotoxic effects of silver nitrate $\left(\mathrm{AgNO}_{3}\right)$ are also less explored in different plant species [18]. The release of silver ions from $\mathrm{AgNO}_{3}$ causes severe toxicity to a variety of organisms such as plants, algae, animals, and bacteria as in (Figure 2) and is based on their inhibitory potential [19]. Published literature has demonstrated more hazardous and toxic effects of $\mathrm{AgNO}_{3}$ on fruiting, flowering, and other physiological mechanisms of plants, which reflects a threat to sustainable agriculture around the world [20]. There are just a few reports that have described the effect of AgNPs on the morphological parameters of pearl millet, while no report has explained the phytotoxic effect of $\mathrm{AgNO}_{3}$ on the morphological, physiological, or biochemical profiles of pearl millet. Therefore, the current study investigated the toxicity levels of $\mathrm{AgNPs}$ and $\mathrm{AgNO}_{3}$ at different concentrations on P. glaucum by analyzing seedling growth, absorption, accumulation, oxidative stress, and antioxidant enzyme activity, which were still unknown.

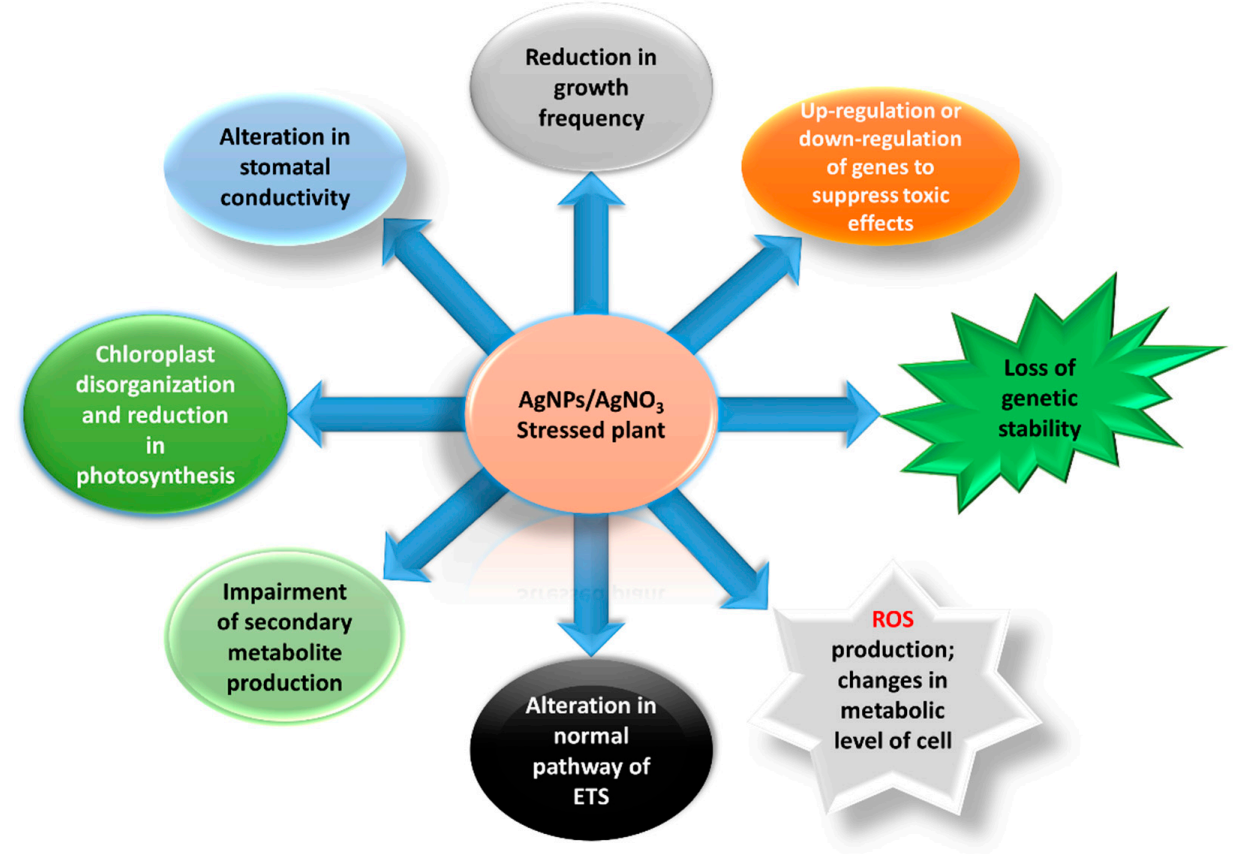

Figure 2. An overview of damaging effects due silver nitrate $\left(\mathrm{AgNO}_{3}\right)$ and synthesized metallic silver nanoparticles (AgNPs).

\section{Materials and Methods}

\subsection{Sliver Nanoparticles and Silver Nitrate}

In the present study, silver nitrate and synthesized silver nanoparticles (AgNPs) were obtained from NANOCS (Nanocs lnc. New York, NY, USA), manufactured according to $>0.75$ A520 units/m 
having $30 \mathrm{~nm}$ size (solution form) as shown in (Figure 3). The dilution of nanoparticles was taken out using stock solution.

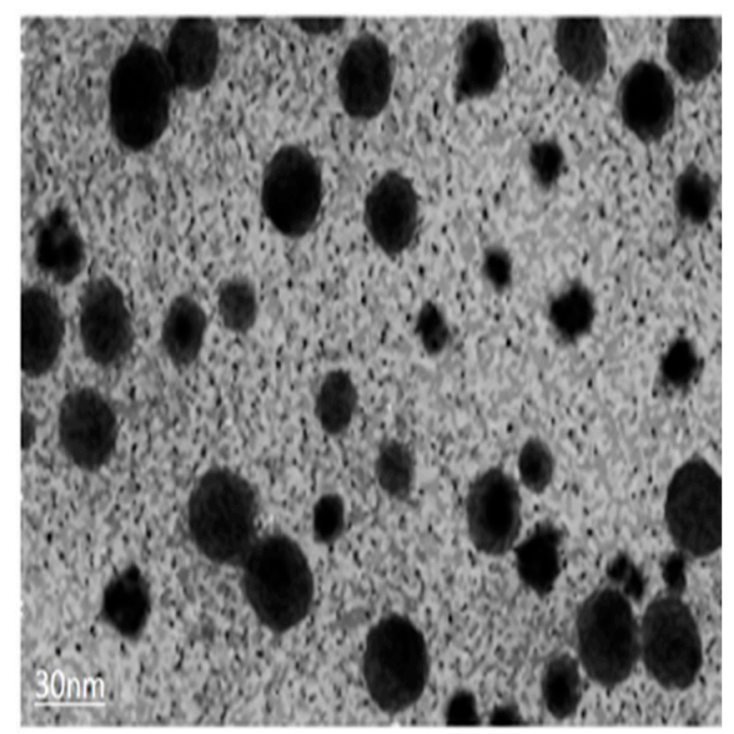

Figure 3. Transmission Electron Microscopy (TEM) of synthesized metallic Silver nanoparticles AgNPs.

\subsection{Plant Material and Sterilization}

The seeds of Pennisetum glaucum were used as an explants for this experiment. Seeds were washed with simple tap water, dipped in ethanol for thirty minutes, then sterilized in $10 \%(\mathrm{v} / \mathrm{v})$ sodium hypochlorite solution $(\mathrm{NaOCl})$ for $10 \mathrm{~min}$, and again washed with autoclaved distilled water. To break dormancy, seeds were soaked in double distilled water for $12 \mathrm{~h}$ and then transferred to a cotton cloth for germination. Uniform sized vigorous seeds were placed in petri plates lined with filter paper containing half strength Hoagland solution and allowed to germinate at $25 \pm 2{ }^{\circ} \mathrm{C}$ for four days in the dark. After germination, five seedlings with almost same length were again placed in half strength Hoagland solution $(40 \mathrm{~mL})$ per pot $(6 \mathrm{~cm} \times 6 \mathrm{~cm})$; placed in a growth chamber at $28 \pm 2{ }^{\circ} \mathrm{C}$ under 11:13 h dark and light periods with light intensity of 200,000 lux; and exposed to $\mathrm{AgNO}_{3}$ and $\mathrm{AgNP}$ treatments for $24 \mathrm{~h}$ at a dosage of 2,4 , and $6 \mathrm{mM}$ along with a control.

\subsection{Growth Parameters}

To assess the growth, ten seedlings from each treatment including the control were randomly selected and their fresh mass was weighed. Root and shoot length was measured using a centimeter scale and root and shoot fresh mass was measured following the method provided by the authors of [21]. The relative water content (RWC) of the leaf was estimated as (FW - DW)/(TW - DW) $\times 100$, where FW fresh weight of leaf tissues, DW dry weight of leaf tissues, and TW turgid weight of leaf after equilibration in distilled water for $24 \mathrm{~h}$.

\subsection{Estimation of Photosynthetic Pigments}

The estimation of total chlorophyll content, fresh leaf samples $(20 \mathrm{mg})$ were taken from the seedlings (control and treated samples). Leaves were grounded and homogenized in $80 \%$ acetone followed by pigment extraction and centrifugation. The absorbance of mixture was measured at $663 \mathrm{~nm}$ and $646 \mathrm{~nm}$ using a spectrophotometer, and chlorophyll content was assessed by following the protocol described by the authors of [22]. 


\subsection{Biochemical Profiling}

\subsubsection{Hydrogen Peroxide Content and Lipid Peroxidation}

Estimation of hydrogen peroxide $\left(\mathrm{H}_{2} \mathrm{O}_{2}\right)$ as ROS in the seedlings was carried out by ferrithiocyanate method, provided by the authors of [23]. The absorbance of samples was measured at $480 \mathrm{~nm}$ and the content of $\mathrm{H}_{2} \mathrm{O}_{2}$ in every sample was calculated using a standard curve.

Lipid peroxidation as malondialdehyde (MDA) was estimated according to the protocol from the work of [24] with some modifications and absorbance was recorded at $532 \mathrm{~nm}$, whereas the non-specific absorbance at $600 \mathrm{~nm}$ was subtracted. Calculation of recorded MDA content was carried out with an extinction coefficient of $155 \mathrm{mM} \mathrm{cm}^{-1}$.

\subsubsection{Proline Content}

Proline content was measured using protocol from the work of [25]. The plant samples were homogenized with a pestle and mortar in $5 \mathrm{~mL}$ of $3 \%$ sulphosalycylic acid. Ninhydrin reagent $(2 \mathrm{~mL})$ and glacial acetic acid $(2 \mathrm{~mL})$ were added to the test tube with $2 \mathrm{~mL}$ of extract. The mixture was placed in a water bath and boiled at $100{ }^{\circ} \mathrm{C}$ for thirty minutes. Then, $6 \mathrm{~mL}$ of toluene was added to reaction mixture after cooling and was transferred to a separate funnel. Thoroughly mixing resulted in the separation of chromophore with toluene and absorbance was measured at $520 \mathrm{~nm}$ using a spectrophotometer.

\subsubsection{Superoxide Dismutase (SOD) Activity}

One of the methods described by the authors of [26] with some modifications was used to measure the SOD activity. One milliliter of reaction mixture was composed of $1 \mathrm{mM}$ Ethylenediamine tetraacetic acid (EDTA), $130 \mathrm{mM}$ methionine, 0.05 molar phosphate buffer ( $\mathrm{pH} 7$ ), $0.02 \mathrm{mM}$ riboflavin, and $0.75 \mathrm{mM}$ nitroblue tetrazolium (NBT). The reaction mixture was placed under the fluorescent light for seven minutes and absorbance was measured at $560 \mathrm{~nm}$. SOD activity was calculated by following the Lambert-Beer law equation:

$$
\mathrm{A}=\varepsilon \mathrm{LC},
$$

where $\mathrm{A}$ is the absorbance, $\varepsilon$ is the extinction coefficient, $\mathrm{L}$ is the length of each wall, and $\mathrm{C}$ is the concentration of enzymes.

\subsubsection{Estimation of Catalases, Peroxidases, Ascorbate Peroxidase Activities, and Protein Contents}

The protocol from the work of [27] was used with some modifications to determine the catalase activity. Enzyme extract $(0.5 \mathrm{~mL})$ was added to $3 \mathrm{~mL}$ of the reaction mixture $(50 \mathrm{mM}$ phosphate buffer, $\mathrm{pH} 7.0$ and $30 \% \mathrm{w} / \mathrm{v}_{2} \mathrm{O}_{2}$ ). The catalase activity was examined at the decrease of absorbance at $240 \mathrm{~nm}$.

The estimation of peroxidase activity was measured by following the method from the work of [28]. Then, $3.0 \mathrm{~mL}$ of the reaction mixture containing $20 \mathrm{mM}$ guaiacol, $10 \mathrm{mM}$ phosphate buffer, and $10 \mathrm{mM} \mathrm{H}_{2} \mathrm{O}_{2}$ was mixed with $0.5 \mathrm{~mL}$ of enzyme extract (heated in water bath at $45^{\circ} \mathrm{C}$ for five minutes before mixing). An increase in absorbance was measured at $470 \mathrm{~nm}$ due to the formation of tetraguaiacol [29].

Ascorbate peroxidase (APX) activity was performed according to the protocols from the work of [30]. Determination of protein contents in each sample were carried out according to protocols from the work of [31].

\subsubsection{Glutathion Reductase (GR) and Guaiacol Peroxidase (GPX) Activity}

GR activity was determined according to methods from the work of [32] by measuring the increase in absorbance range due to the presence of 5,5-dithiobis-2-nitrobenzoic acid (DTNB) and oxidized 
glutathione. GR activity (one unit) might be referred to as the quantity of enzyme needed to cause oxidation of NADPH $(1.0 \mu \mathrm{m})$ at neutral $\mathrm{pH}(7.5)$.

GPX activity was assessed by the method from the authors of [28] by evaluating the formation of tetra guaiacol at $470 \mathrm{~nm}$. One unit of GPX was the amount required to catalyze the conversion of $\mathrm{H}_{2} \mathrm{O}_{2}$ $(1.0 \mu \mathrm{mol})$ per min.

\subsubsection{Estimation of Total Phenolic Content (TPC)}

For TPC estimation, Folin-Ciocalteu reagent $(0.75 \mathrm{~mL})$ was added to $100 \mu \mathrm{l}$ plant extract, gently mixed, and placed them at $22^{\circ} \mathrm{C}$ for five minutes. Then, $0.75 \mathrm{~mL}$ of $\mathrm{Na}_{2} \mathrm{CO}_{3}$ solution was added to the mixture and kept at $22{ }^{\circ} \mathrm{C}$ for ninety minutes. The final results were concluded by checking the sample absorbance at $725 \mathrm{~nm}$ with a UV/vis-DAD spectrophotometer [33].

\subsubsection{Estimation of Total Flavonoids Content (TFC)}

For the estimation of TFC, an $\mathrm{AICI}_{3}-\mathrm{NaNO}_{2}-\mathrm{NaOH}$ reaction complex was used according to protocol given by the authors of [34]. A total of $0.2 \mathrm{~mL}$ extract was added to $3.5 \mathrm{~mL}$ distilled water. Furthermore, $(0.15 \mathrm{~mL}) 5 \% \mathrm{NaNO}_{2},(0.15 \mathrm{~mL}) 10 \% \mathrm{AlCl}_{3}$, and $(1 \mathrm{~mL}) 1 \mathrm{M} \mathrm{NaOH}$ were added to the mixtureat equal $5 \mathrm{~min}$ time intervals, and placed at normal room temperature for $15 \mathrm{~min}$. Reaction absorbance was measured at $510 \mathrm{~nm}$ using a UV/vis-DAD spectrophotometer.

\subsection{Experimental Design and Statistical Analysis}

Experiments were performed twice with three replicates $(n=6)$. Means and standard errors $( \pm)$ were calculated by analysis of variance (one-way). The comparison of the means (control + treatments) was confirmed by Duncan's multiple range test at $p<0.05$.

\section{Results}

\subsection{Growth Parameters}

The induced impact of AgNPs and $\mathrm{AgNO}_{3}$ on the seedlings' growth of P.glaucum was analyzed and the results are presented in Table 1. Root length, shoot length, and fresh and dry biomass were measured to evaluate the phytotoxic effects of $\mathrm{AgNPs}_{\mathrm{N}}$ and $\mathrm{AgNO}_{3}$ on the growth of P.glaucum seedlings. The results indicated that $\mathrm{AgNO}_{3}$ significantly $(p<0.05)$ reduced the root and shoot length with the increasing concentration $(2 \mathrm{mM}, 4 \mathrm{mM}, 6 \mathrm{mM})$, while AgNPs showed a minor reduction when both were compared with the control. Root and shoot length were reduced to $41 \%$ and $21 \%$ at $2 \mathrm{mM} \mathrm{AgNO}_{3}$, whereas AgNPs under the same treatment were noted to cause a reduction of $28 \%$ and $15 \%$ for root and shoot length, respectively (Table 1), which indicated a smaller decrease in growth parameters at a lower concentration. However, a significant reduction was observed at a higher concentration $(6 \mathrm{mM})$ of $\mathrm{AgNO}_{3}$ with a $68 \%$ and $36 \%$ in root and shoots length when compared with AgNPs, which demonstrated a reduction of $61 \%$ and $31 \%$ in root and shoot, respectively, lesser than the $\mathrm{AgNO}_{3}$. Fresh and dry biomass of seedlings exposed to $\mathrm{AgNO}_{3}$ and $\mathrm{AgNPs}$ was also observed to be lower than control. $\mathrm{AgNO}_{3}(2 \mathrm{mM}$ ) reduced the fresh and dry biomass of seedlings by $38 \%$ and $20 \%$, respectively, while on the other hand, AgNPs at same concentration caused a reduction in fresh and dry biomass only by $14 \%$ and $10 \%$, respectively. A greater reduction in biomass was recorded with increasing the concentration of both $\mathrm{AgNO}_{3}$ and AgNPs. A higher concentration $(6 \mathrm{mM})$ of AgNPs reduced the fresh and dry biomass of seedlings by up to $47 \%$ and $35 \%$, respectively, while the reduction was $55 \%$ for fresh biomass and $45 \%$ for dry biomass with $6 \mathrm{mM} \mathrm{AgNO}_{3}$. Compared with the control, the RWC was gradually decreased to $28 \%$ and $26 \%$ at $2 \mathrm{mM}$ for $\mathrm{AgNO}_{3}$ and $\mathrm{AgNPs}$, whereas a further decline in RWC was noted under all treatments of $\mathrm{AgNO}_{3}$ than AgNPs (Table 1). These presented results indicated that $\mathrm{AgNO}_{3}$ possessed more damaging effects on growth parameters of P.glaucum than AgNPs. 
Table 1. Effect of AgNPs and $\mathrm{AgNO}_{3}$ on root length (RL) (cm), shoot length (SL) (cm), fresh weight (FW) (g), dry weight (DW) (g), and relative water contents (RWC) $(\%)$ of pearl millet (Pennisetum glaucum L.) seedlings. Each experiment was performed twice with three replicates $(n=6)$. Means and standard errors $( \pm)$ were calculated by analysis of variance (one-way). A comparison of the means (control + treatments) was confirmed by Duncan's multiple range test at $p<0.05$.

\begin{tabular}{|c|c|c|c|c|c|c|c|c|c|c|}
\hline \multirow{3}{*}{ Treatments } & \multicolumn{5}{|c|}{ AgNPs } & \multicolumn{5}{|c|}{$\mathrm{AgNO}_{3}$} \\
\hline & \multicolumn{10}{|c|}{ Growth Parameters } \\
\hline & RL & SL & FW & DW & RWC & RL & SL & FW & DW & RWC \\
\hline Control & $12.37 \pm 0.96^{c}$ & $7.47 \pm 0.23^{c}$ & $0.131 \pm 0.006^{c}$ & $0.020 \pm 0.0005^{\mathrm{d}}$ & $95.17 \pm 0.79^{d}$ & $12.37 \pm 0.96^{c}$ & $7.47 \pm 0.23^{c}$ & $0.131 \pm 0.006^{c}$ & $0.020 \pm 0.0005^{\mathrm{d}}$ & $95.17 \pm 0.79^{d}$ \\
\hline $2 \mathrm{mM}$ & $8.87 \pm 0.99(28)^{b}$ & $6.33 \pm 0.26(15)^{b}$ & $0.112 \pm 0.003(14)^{b}$ & $0.018 \pm 0.0001(10)^{c}$ & $90.01 \pm 1.47(10)^{\mathrm{c}}$ & $7.27 \pm 0.62(41)^{b}$ & $5.87 \pm 0.22^{c}(21)^{b}$ & $0.081 \pm 0.003(38)^{b}$ & $0.0164 \pm 0.0001(20)^{\mathrm{c}}$ & $83.02 \pm 1.68(13)$ \\
\hline $4 \mathrm{mM}$ & $7.20 \pm 0.45(41)^{b c}$ & $5.90 \pm 0.23(21)^{b}$ & $0.075 \pm 0.002(43)^{\mathrm{a}}$ & $0.016 \pm 0.0002(20)^{b}$ & $80.54 \pm 1.83(15)^{b}$ & $5.17 \pm 0.33(58)^{\mathrm{a}}$ & $5.10 \pm 0.20^{c}(32)^{a}$ & $0.068 \pm 0.001(48)^{a b}$ & $0.0143 \pm 0.0002^{c}(30)^{b}$ & $72.04 \pm 2.16(24)$ \\
\hline $6 \mathrm{Mm}$ & $4.80 \pm 0.35(61)^{\mathrm{a}}$ & $5.13 \pm 0.18(31)^{a}$ & $0.069 \pm 0.002(47)^{\mathrm{a}}$ & $0.0132 \pm 0.0002(35)^{\mathrm{a}}$ & $70.28 \pm 1.59(26)^{\mathrm{a}}$ & $3.90 \pm 0.21(68)^{a}$ & $4.77 \pm 0.14^{\mathrm{c}}(36)^{\mathrm{a}}$ & $0.058 \pm 0.002(55)^{\mathrm{a}}$ & $0.0114 \pm 0.0003^{c}(45)^{a}$ & $63.10 \pm 1.49(28)^{2}$ \\
\hline
\end{tabular}

Similar superscript letters such as $\left({ }^{\mathrm{a}},{ }^{\mathrm{b}},{ }^{\mathrm{c}}\right.$ and $\left.{ }^{\mathrm{d}}\right)$ within a column indicate that means were not significantly differe between treatments $p<0.05$. 


\subsection{Photosynthetic Pigments and Protein Contents}

Total chlorophyll and carotenoid content decreased under all treatments $(2 \mathrm{mM}, 4 \mathrm{mM}$, and $6 \mathrm{mM})$ of $\mathrm{AgNO}_{3}$ and $\mathrm{AgNPs}$, whereas the effect of AgNPs at the similar dose was slightly lesser when compared with the control (Figure $4 \mathrm{a}, \mathrm{b}$ ). It was obvious that the trend of reduction in carotenoids was less than the chlorophyll for all treatments. However, the total protein content in P. glaucum seedlings exposed to various doses of $\mathrm{AgNO}_{3}$ and $\mathrm{AgNPs}$ seemed to be less than the control (Figure 1c). At a high concentration of $\mathrm{AgNO}_{3}(6 \mathrm{mM})$, significant reduction was recorded (38\%) with respect to $\mathrm{AgNPs}$ at the same dose (24\%) when compared with the control. Furthermore, at $2 \mathrm{mM}$ of $\mathrm{AgNO}_{3}$ and AgNPs, a reduction in the percentage of total protein content of $15 \%$ and $9 \%$, respectively, was noticed. These results clearly show that $\mathrm{AgNO}_{3}$ had a more destructive effect than AgNPs.

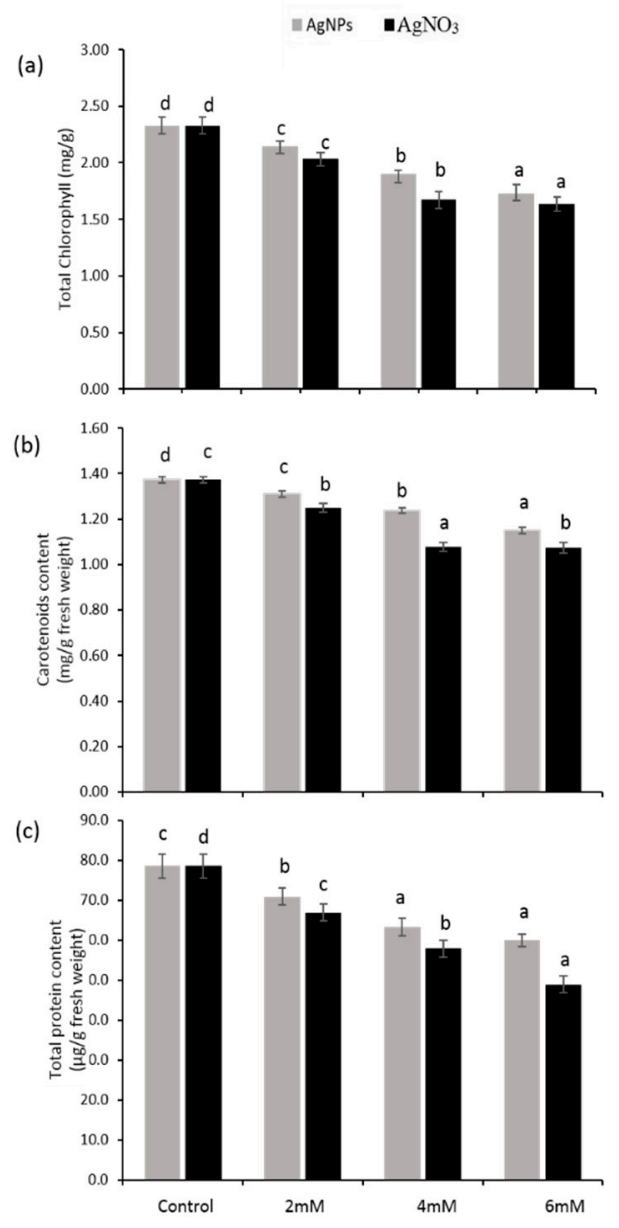

Figure 4. Total chlorophyll content (a), carotenoids content (b) and total protein content (c) contents in the seedlings of P. glaucum L. exposed to AgNPs and $\mathrm{AgNO}_{3}$. The Experiment was performed twice with three replicates $(n=6)$. Means and standard errors $( \pm)$ were calculated by analysis of variance (one way). A comparison of the means (control + treatments) was confirmed by Duncan's Multiple Range Test at $p<0.05$.

Chlorophyll fluorescence provided the state of health for the photosynthetic system in the leaves. A significant decrease in $\mathrm{Fv} / \mathrm{Fm}$ value was recorded when seedlings were exposed to $\mathrm{AgNO}_{3}$ as compared with the control (Figure $5 \mathrm{c}$ ). $\mathrm{AgNO}_{3}$ at the concentrations $(2 \mathrm{mM}, 4 \mathrm{mM}$, and $6 \mathrm{mM}$ ) strongly influenced the photosynthetic performance of $P$. glaucum seedlings when compared with the AgNPs and the control. Figure $5 \mathrm{a}, \mathrm{b}$ shows a lower value for photochemical quenching (qP), but a high value for non-photochemical quenching (NPQ) was observed in the seedlings exposed to given treatments. 

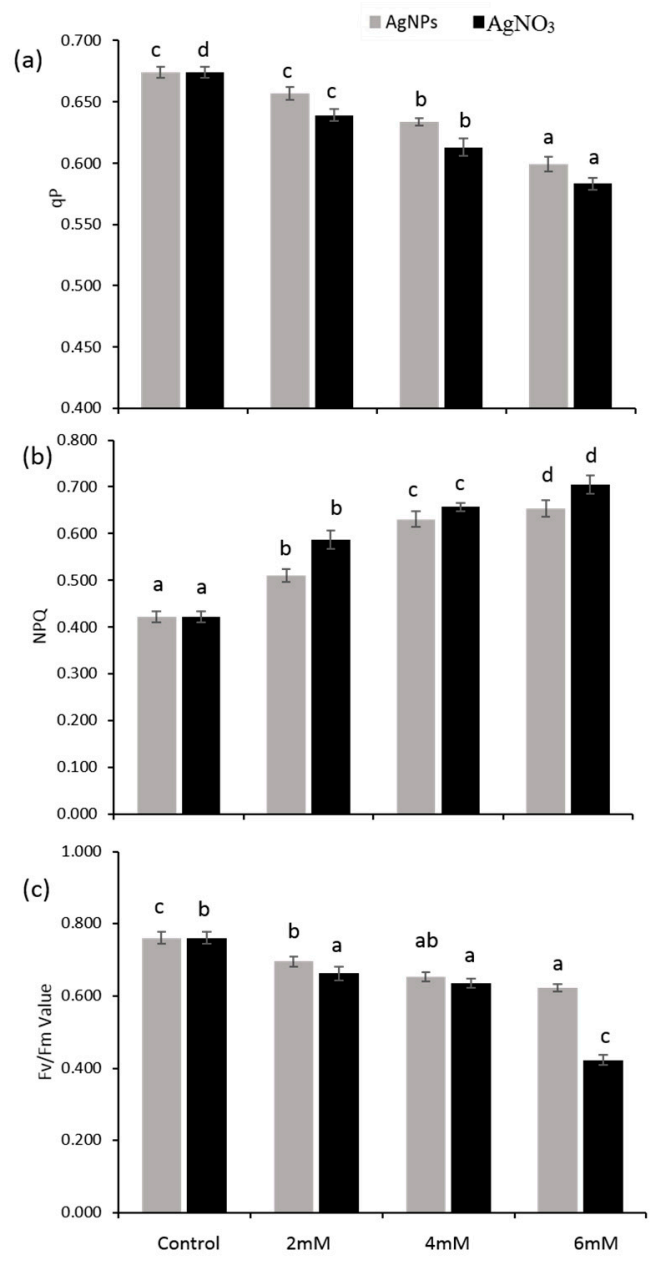

Figure 5. Photochemical quenching (a), NPQ, non-photochemical quenching (b) and Fv/Fm values (c) of P. glaucum L. seedlings exposed to AgNPs and $\mathrm{AgNO}_{3}$. The Experiment was performed twice with three replicates $(n=6)$. Means and standard errors $( \pm)$ were calculated by analysis of variance (one way). And the A comparison of the means (control + treatments) was confirmed by Duncan's Multiple Range Test at $p<0.05$.

\subsection{Oxidative Damage}

The results pertaining to hydrogen peroxide $\left(\mathrm{H}_{2} \mathrm{O}_{2}\right)$ contents in the seedlings of pearl millet exposed to variable concentration of $\mathrm{AgNO}_{3}$ and $\mathrm{AgNPs}$ are presented in Figure 6a. Compared with the control, silver nitrate- and silver nanoparticles-treated seedlings significantly $(p<0.05)$ enhanced the hydrogen peroxide accumulation, while $\mathrm{AgNO}_{3}$-treated seedlings exhibited a higher $\mathrm{H}_{2} \mathrm{O}_{2}$ level than AgNPs.

\subsection{Lipid Peroxidation as MDA Contents}

The data shown in Figure $6 \mathrm{~b}$ indicate that $\mathrm{AgNO}_{3}$ and $\mathrm{AgNPs}$ caused significant damage to the cellular membrane as melondialdehyd (MDA) contents, the value of lipid peroxidation was progressively raised by increasing the concentration of silver nitrate and silver nanoparticles $(2 \mathrm{mM}$, $4 \mathrm{mM}$, and $6 \mathrm{mM})$. $\mathrm{AgNO}_{3}$-treated seedlings at $6 \mathrm{mM}$ showed significantly $(p<0.05)$ higher accumulation of MDA $(84.9 \mu \mathrm{M} / \mathrm{g}$ dry wt) than AgNPs seedlings $(72.7 \mu \mathrm{M} / \mathrm{g}$ dry wt) and control seedlings $(23.2 \mu \mathrm{M} / \mathrm{g}$ dry wt). While on the other hand, MDA content in $\mathrm{AgNO}_{3}$ and AgNPs treated seedlings at $2 \mathrm{mM}$ was $(46.5 \mu \mathrm{M} / \mathrm{g}$ dry $w \mathrm{t})$ and $(35.7 \mu \mathrm{M} / \mathrm{g}$ dry $w \mathrm{t})$ respectively. 


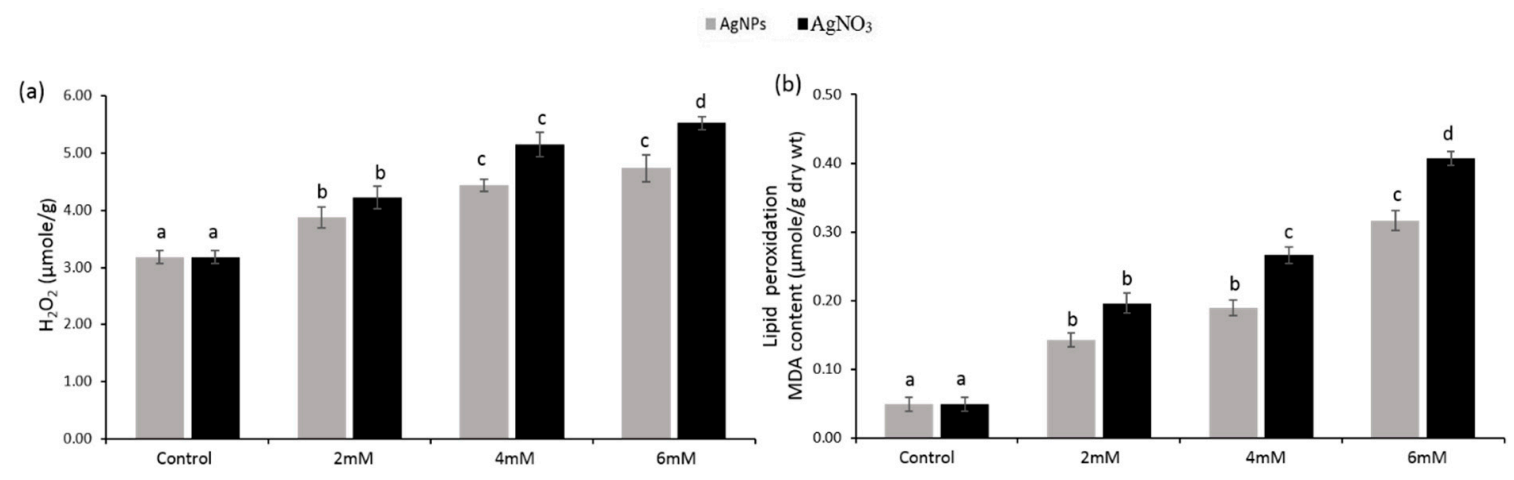

Figure 6. Hydrogen peroxide $\left(\mathrm{H}_{2} \mathrm{O}_{2}\right)$ (a) lipid peroxidation (b) as melondialdehyd (MDA) content in the seedlings of P. glaucum L. exposed to AgNPs and $\mathrm{AgNO}_{3}$. Experiments were performed twice with three replicates $(n=6)$. Means and standard errors $( \pm)$ were calculated by analysis of variance (one-way). A comparison of the means (control + treatments) was confirmed by Duncan's multiple range test at $p<0.05$.

\subsection{Enzymatic Antioxidants}

The results related to enzymatic antioxidants such as superoxide dismutase (SOD), ascorbate peroxidase (APX), catalase (CAT), peroxidase (POD), guaiacol peroxidase (GPX), and glutathion reductase (GR) are presented in Figures 7 and 8. SOD activity in both treated seedlings exposed to $\mathrm{AgNO}_{3}$ and AgNPs at a $2 \mathrm{mM}$ dose exhibited a higher rate (25\% and $15 \%$, respectively) when compared with the control. As their concentration increased to $6 \mathrm{mM}$, a progressive and significant $(p<0.05)$ trend was recorded that boosted the SOD activity up to $42 \%$ for $\mathrm{AgNO}_{3}$ and $34 \%$ for AgNPs (Figure $7 \mathrm{a}$ ). Further decline in SOD activity was noticed in the seedlings following $\mathrm{AgNO}_{3}$ contact when compared with AgNPs, which disclosed more harmful impact of silver nitrate on P.glaucum. Ascorbate peroxidase (APX) is highly responsible for disassociating hydrogen peroxide into $\mathrm{H}_{2} \mathrm{O}$ and oxygen using ascorbate (electron donor), whereas CAT dissociates hydrogen peroxide into $\mathrm{H}_{2} \mathrm{O}$ and oxygen without using any external reductants. Significant $(p<0.05)$ inhibition of CAT and APX activity was noted in P. glaucum seedlings with respect to the increase in $\mathrm{AgNO}_{3}$ and AgNPs dose (6 mM) up to $64 \%$ and $47 \%$, and $29 \%$ and $41 \%$, respectively, by comparing the control plants. The rate of inhibition in their activities under AgNPs treatment was recorded to be less than silver nitrate, as presented in Figure $7 \mathrm{~b}, \mathrm{~d}$.

P. glaucum seedlings under $\mathrm{AgNO}_{3}$ and AgNPs treatment $(2 \mathrm{mM})$ exhibited lower peroxidase (POD), glutathione reductase (GR), and guaiacol peroxidase (GPX) activity $(26 \%, 42 \%$, and $31 \%$, respectively; and $14 \%, 12 \%$, and $18 \%$, respectively), while their activity was gradually decreased up to $48 \%, 86 \%$, and $61 \%$, and $41 \%, 53 \%$, and $51 \%$, respectively, by increasing the concentration ( $6 \mathrm{mM}$ ) of silver nitrate and silver nanoparticles, respectively. High doses of both caused a down-regulating effect on POD, GR, and GPX activities, which showed a significant $(p<0.05)$ reduction, but their level was less under AgNPs than $\mathrm{AgNO}_{3}$ when compared with the control (Figures 7c and 8a,b ). 


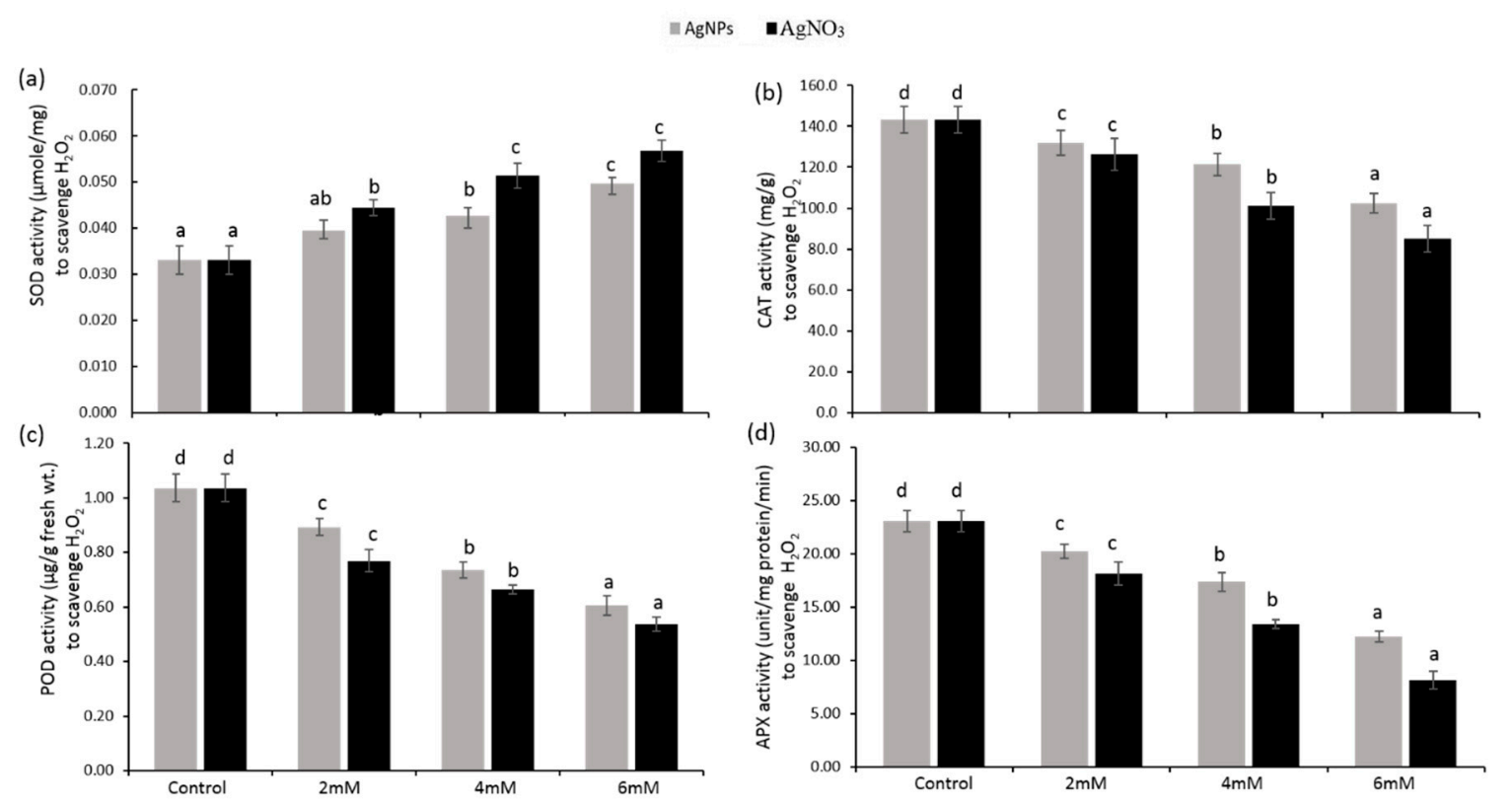

Figure 7. Activity of superoxide dismutase (SOD) (a), catalase (CAT) (b), peroxidase (POD) (c), and ascorbate peroxidase (APX) (d) in P. glaucum L. seedlings exposed to AgNPs and $\mathrm{AgNO}_{3}$. Experiments were performed twice with three replicates $(n=6)$. Means and standard errors $( \pm)$ were calculated by analysis of variance (one-way). A comparison of the means (control + treatments) was confirmed by Duncan's multiple range test at $p<0.05$.

$=\mathrm{AgNPS} \quad \mathrm{AgNO}_{3}$
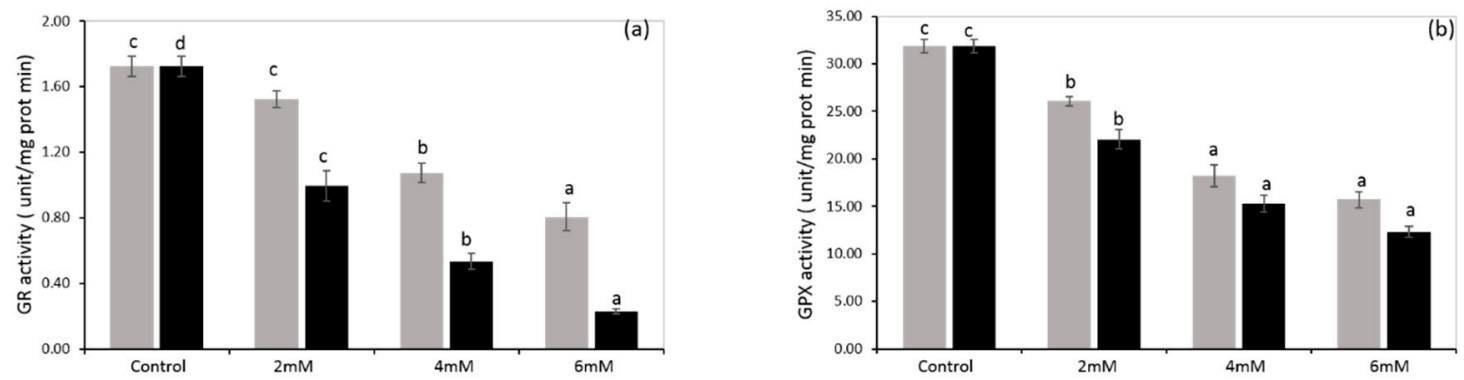

Figure 8. Glutathione reductase activity (a) and guaiacole peroxidase activity (b) in the P. glaucum L. seedlings exposed to AgNPs and $\mathrm{AgNO}_{3}$. Experiments were performed twice with three replicates $(n=6)$. Means and standard errors $( \pm)$ were calculated by analysis of variance (one way). A comparison of the means (control + treatments) was confirmed by Duncan's multiple range test at $p<0.05$.

\subsection{Non-Enzymatic Antioxidants}

Table 2 shows the response of non-enzymatic antioxidants such as proline contents, and total phenolic and flavonoid content under different concentrations of $\mathrm{AgNO}_{3}$ and $\mathrm{AgNPs}$. Control seedlings exhibited relatively lower contents of non-enzymatic antioxidants, while their levels increased as the doses of $\mathrm{AgNO}_{3}$ and $\mathrm{AgNPs}$ increased. For all treatments of $\mathrm{AgNO}_{3}$ and $\mathrm{AgNPs}$, proline content was recorded to be less than the control, whereas others (TPCs and TFCs) showed a progressive effect. An enhancing trend of non-enzymatic antioxidants seemed to be greater in P.glaucum seedlings exposed to $5 \mathrm{mM}$ of $\mathrm{AgNO}_{3}$ than AgNPs, presenting proline (44\%, 41\%), TPCs $(38 \%, 33 \%)$, and TFCs $(52 \%, 48 \%)$, respectively when compared with control. Levels of non-enzymatic antioxidants were significantly $(p<0.05)$ elevated with respect to the exposure of both $\mathrm{AgNO}_{3}$ and $\mathrm{AgNPs}$ compared with the control, but the higher activity was attributable to $\mathrm{AgNO}_{3}$, as shown in Table 2 . 


\section{Discussion}

The current study was carried out to examine the phytotoxic impact of $\mathrm{AgNO}_{3}$ and $\mathrm{AgNPs}$ on P.glaucum seedlings. A significant decrease in growth parameters in P.glaucum seedlings exposed to variable doses of $\mathrm{AgNO}_{3}$ and $\mathrm{AgNPs}$ was presented (Table 1). Moreover, stunted plant growth, short leaf length, and distortion of shoots were also analyzed, which might have a direct link with the poor photosynthetic performance of the seedlings. The toxic impact of AgNPs on root length, shoot length, fresh and dry biomass, photosynthetic pigments, and biochemical profiles was observed to be less for $\mathrm{AgNO}_{3}$ when both were compared with controls. A similar study was reported by the authors of [35], where $\mathrm{AgNO}_{3}$ severely reduced the growth parameters by increasing the uptake of silver in plants. More accumulation of silver from $\mathrm{AgNO}_{3}$ caused inhibition of grain germination, reduction in root and shoot length, and a decrease in the chlorophyll pigments in barley seedlings [36]. However, AgNPs possessed no more toxic effect on the plant morphology and increased the cell division process by enhancing the hormonal activities, dependent on the size of the NPs [37]. The published literature suggests that the response to $\mathrm{Ag}^{+}$(bulk or nano) may be positive or negative, particularly depending on the interaction of proteins with the plant internal metabolism. Although AgNPs inhibited the root elongation in corn, their application also enhanced the morphological characteristics including seed germination, root and shoot length, and biomass in watermelon and cucumber [10,38]. Furthermore, alterations in root and shoot length were also determined from the time of germination, which might be the result of contact with AgNPs, which may create 'nano holes' in the seed coats and make their entry easier to seeds via the seed coat, resulting in enhanced germination. The slow and slight release of silver ions $\left(\mathrm{Ag}^{+}\right)$could be a second major reason that $\mathrm{Ag}$-nanoparticles have no deleterious effects. Penetration, accumulation, and translocation of AgNPs appears to be strongly dependent on their size, shape, concentration, and type of plant species [37]. Our results reaffirmed those of the authors of [39], who described $\mathrm{AgNO}_{3}$ as more toxic to seedlings' growth and morphology. Interestingly, in the present study, no more harmful effects of AgNPs on P.glaucum seedlings were observed even at a high concentration; these findings strongly correlate with those of the authors of [40], who reported high germination rate and growth parameters in R.cummunis exposed to higher doses of AgNPs.

In the present study, seedlings exposed to AgNPs had a minor reduction in root and shoot length (Table 1). However, few reports have described that nano silver improved the water uptake through accumulation, and transportation of $\mathrm{Ag}^{+}$in roots caused distortion of epidermal structures and changed the anatomical features of plants [41]. Further distortion of roots and damage to roots were observed in the seedlings treated with $\mathrm{AgNO}_{3}$, while AgNPs treatment did not behave like $\mathrm{AgNO}_{3}$ treatment. Our study strongly matches with previous findings that more silver ions in roots alter its structure and also associate with translocation mechanism in plants [42].

Photosynthetic parameters can be easily measured by estimating chlorophyll fluorescence under stress and normal growth conditions [42]. The results showed a significant reduction in total chlorophyll (Figure 4a) dependent on the decrease in $\mathrm{Fv} / \mathrm{Fm}$ and qP values in P.glaucum seedlings exposed to $\mathrm{AgNO}_{3}$, whereas a lower reduction in photosynthetic parameters was noticed in the case of AgNPs-treated seedlings when both were compared with the control (Figure 2a,b). Higher chlorophyll content and high efficiency of photosynthetic system was reported in Brassica seedlings exposed to AgNPs [43]. Various stresses caused more reduction in the activity of photosystem II, which ultimately decreased the $\mathrm{Fv} / \mathrm{Fm}$ and $\mathrm{qP}$ value and alternatively declined the plant chlorophyll content [44]. Our results demonstrated that a decline in the $\mathrm{Fv} / \mathrm{Fm}$ and qP value (Figure $5 \mathrm{a}, \mathrm{c}$ ) resulted in a decreased chlorophyll content, which was strongly associated with lower biomass accumulation in P. glaucum seedlings. Previous data showed that NPQ values increased when plants were facing stress conditions, which led to the down-regulation of photosystem II and inhibited the functioning of the electron transport chain (ETC) [45]. Present findings demonstrated high values of NPQ in the seedlings exposed to $\mathrm{AgNO}_{3}$, but lower in AgNPs, which indicates proper functioning of the ETC in the seedlings treated with silver nanoparticles (Figure 5b). The present results demonstrated that more ROS production decreased the seedlings' growth and caused protein oxidation and lipid peroxidation. Damaging effects of AgNPs 
on oxidative stress seemed to be lower with $\mathrm{AgNO}_{3}$ when compared with the control. A recent study reported that a decline in growth attributes might be the result of destructive impacts of ROS on the photosynthetic machinery and may be involved in oxidative stress [14]. Previously, it was described that stress condition triggers the production of ROS and accelerates the oxidative damage [46]. To cope with oxidative stress inside the cells, plants have a well-developed antioxidant defense system.

A significant $(p<0.05)$ reduction in enzymatic antioxidants such as APX (Figure 7d), CAT (Figure 7b), POD (Figure 7c), GR (Figure 8a), and GPX (Figure 8b) was recorded in the seedlings exposed to $\mathrm{AgNO}_{3}$ when compared with AgNPs and the control. The authors of [47] reported that CuNPs and their precursor, $\mathrm{CuCl}_{2}$, decreased the CAT activity as a result of the direct interaction of copper with thiol moieties of protein, and altered the CAT structure, which led to inhibition of its functioning. A similar mechanism might be regulated by Ag in P. glaucum seedlings, resulting in enhanced ROS production along with the suppression of enzymatic antioxidants. Previously, it was investigated that a higher concentration of AgNPs caused a reduction in CAT and APX activity in potato seedlings [48]. In another study [49], it was revealed that AgNPs had no damaging effects on wheat seedlings, though their application boosted the early growth of brassica by controlling the antioxidant capacity [43]. Exposure to stress in plants resulted in high ROS production, which affected the plant metabolism by damaging the defense mechanism and consequently decreasing the antioxidant activities [50,51]. Under stress conditions, GR plays a key role to regulate the ascorbate-glutathione cycle and converts the oxidized glutathione to glutathione [52], whereas $\mathrm{AgNO}_{3}$ had more toxic effects on plants related to morphology, physiology, and bioaccumulation [53]. In the current study, we observed that P.glaucum seedlings showed a lower activity of these antioxidants when exposed to a higher concentration of $\mathrm{AgNO}_{3}$ and $\mathrm{AgNPs}$, but a greater reduction was found in the case of $\mathrm{AgNO}_{3}$.

Increased POD activity under heavy metal stress increased the growth and development of plant seedlings, which alternatively minimized the oxidative damage [54]. $\mathrm{AgNO}_{3}$ treatment aroused the POD activity in radish seedlings to cope with oxidative stress caused by ROS production, whereas a non-significant increase in POD activity was recorded after exposure to AgNPs [55]. Moreover, another study revealed that AgNPs increased ROS in wheat seedlings, which led to oxidative stress in plants [56]. Environmental stress led to more production of ROS and plants need to scavenge ROS for their normal growth, but stress altered the enzymatic activities involved in scavenging ROS [57]. However, in the recent study, lower POD activity was observed under higher doses of $\mathrm{AgNO}_{3}$ and $\mathrm{AgNPs}$, which might be the result of greater ROS production and alteration in the structure of antioxidants, but a non-significant increase in ROS due to AgNPs was recorded. Our results are in line with those of the work of [58], which described that AgNPs involved in the blockage of electron transfer causes oxidative stress. Although, in the present study, P.glaucum seedlings exposed to AgNPs showed a reduction in CAT, APX, GPX, and POD activities when compared with the control a comparatively lower reduction was noted when compared with $\mathrm{AgNO}_{3}$ (Figures 7 and 8), this might indicate that AgNPs have a strong interaction with proteins found in the lipid bilayer and cytosol; thus, altering its configuration and negatively influencing the antioxidant define systems [59]. Previously, it has been reported that the impact of AgNPs on antioxidant enzymes varied with plant species, dosage, and time duration of AgNPs applied [60].

In addition, plants' cells also contain a variety of non-enzymatic antioxidants such as proline, flavonoids, and phenolic contents to mitigate the toxic effects of ROS. Previously published literature has revealed that proline content was increased when plants were exposed to various types of stresses [61], and the same trend was noted in the current study (Table 2). A significant $(p<0.05)$ increase in proline contents was recorded in the seedlings exposed to a higher concentration of $\mathrm{AgNO}_{3}$, which reflected a greater stress condition. Accumulation of proline to a higher level under stress indicates the that proline as a cytoplasmic osmolyte protects the protein against denaturation [62] 
Table 2. Effect of silver nanoparticles (AgNPs) and silver nitrate $\left(\mathrm{AgNO}_{3}\right)$ on non-enzymatic antioxidants such as proline content ( $\mu \mathrm{g} / \mathrm{mg}$ fresh weight), total flavonoid content ( $\mu \mathrm{g} / \mathrm{mg}$ fresh weight), and total phenolic content $(\mu \mathrm{g} / \mathrm{mg}$ fresh weight) of pearl millet (Pennisetum glaucum L.) seedlings. Experiments were performed twice with three replicates $(n=6)$. Means and standard errors $( \pm)$ were calculated by analysis of variance (one-way). A comparison of the means (control + treatments) was confirmed by Duncan's multiple range test at $p<0.05$.

\begin{tabular}{ccccccc}
\hline Treatment & \multicolumn{7}{c}{ AgNPs } & Non-Enzymatic Antioxidants \\
\hline & Proline & TFCs & TPCs & Proline & TFCs & TPCs \\
\cline { 2 - 7 } Control & $1.22 \pm 0.037^{\mathrm{a}}$ & $\begin{array}{c}2.06 \pm 0.043 \\
(41)^{\mathrm{d}}\end{array}$ & $1.56 \pm 0.032^{\mathrm{a}}$ & $1.22 \pm 0.037^{\mathrm{a}}$ & $0.59 \pm 0.023^{\mathrm{a}}$ & $\begin{array}{c}1.22 \pm 0.023 \\
(52)^{\mathrm{d}}\end{array}$ \\
\hline \multirow{2}{*}{$2 \mathrm{mM}$} & $\begin{array}{c}1.59 \pm 0.027 \\
(23)^{\mathrm{b}}\end{array}$ & $\begin{array}{c}0.71 \pm 0.022 \\
(17)^{\mathrm{b}}\end{array}$ & $\begin{array}{c}1.75 \pm 0.021 \\
(11)^{\mathrm{b}}\end{array}$ & $\begin{array}{c}1.72 \pm 0.032 \\
(29)^{\mathrm{b}}\end{array}$ & $\begin{array}{c}0.84 \pm 0.015 \\
(30)^{\mathrm{b}}\end{array}$ & $\begin{array}{c}1.84 \pm \\
0.021(15)^{\mathrm{b}}\end{array}$ \\
\hline \multirow{2}{*}{$4 \mathrm{Mm}$} & $\begin{array}{c}1.83 \pm 0.026 \\
(33)^{\mathrm{c}}\end{array}$ & $\begin{array}{c}0.85 \pm 0.020 \\
(30)^{\mathrm{c}}\end{array}$ & $\begin{array}{c}1.92 \pm 0.024 \\
(19)^{\mathrm{c}}\end{array}$ & $\begin{array}{c}1.93 \pm 0.026 \\
(37)^{\mathrm{c}}\end{array}$ & $\begin{array}{c}0.94 \pm 0.017 \\
(37)^{\mathrm{c}}\end{array}$ & $\begin{array}{c}2.00 \pm 0.055 \\
(22)^{\mathrm{c}}\end{array}$ \\
\hline \multirow{2}{*}{$6 \mathrm{Mm}$} & $\begin{array}{c}2.06 \pm 0.043 \\
(41)^{\mathrm{d}}\end{array}$ & $\begin{array}{c}1.13 \pm 0.023 \\
(48)^{\mathrm{d}}\end{array}$ & $\begin{array}{c}2.32 \pm 0.028 \\
(33)^{\mathrm{d}}\end{array}$ & $\begin{array}{c}2.16 \pm 0.023 \\
(44)^{\mathrm{d}}\end{array}$ & $\begin{array}{c}1.22 \pm 0.023 \\
(52)^{\mathrm{d}}\end{array}$ & $\begin{array}{c}2.53 \pm 0.026 \\
(38)^{\mathrm{d}}\end{array}$ \\
\hline
\end{tabular}

Similar superscript letters such as $\left({ }^{a},{ }^{b}, c\right.$ and $\left.{ }^{d}\right)$ within a column indicate that means were not significantly differe between treatments $p<0.05$

Seedlings treated with $\mathrm{AgNO}_{3}$ showed higher levels of TPC and TFC when compared with both AgNPs and controls; AgNPs treatment also considerably enhanced the TPC and TFC levels, but possessed less toxic effects than $\mathrm{AgNO}_{3}$ (Table 2). Similar findings were reported by the authors of [53], who noted that AgNPs produce a higher TPC. Our results indicated that $\mathrm{AgNO}_{3}$ negatively affected all the plant aspects toward their survival by increasing uptake and accumulation of $\mathrm{Ag}$ from $\mathrm{AgNO}_{3}$.

\section{Conclusions}

A recent study revealed that $\mathrm{AgNO}_{3}$ possessed more damaging effects on the growth of P. glaucum seedlings. However, AgNPs even at high concentrations did not severely affect the morphology and physiology of seedlings, unlike $\mathrm{AgNO}_{3}$. High SOD activity and a greater MDA content reflect the greater accumulation of ROS, which leads to higher membrane damage and blockage of the metabolic pathway of a cell. Thus, from the present study, it can be clearly concluded that fast and bulk release of $\mathrm{Ag}^{+}$from $\mathrm{AgNO}_{3}$ and $\mathrm{AgNPs}$ causes a strong interaction with roots and also distributes to upper parts, which cause severe stress in the seedlings. Our results indicate that $\mathrm{AgNO}_{3}$ caused a greater reduction in total chlorophyll, carotenoid, and total protein content, which led to a greater loss of yielding due to high toxicity, whereas smaller-sized metallic AgNPs also had rapid interactions with plants and reduced the growth by impairing plant normal metabolism, but their toxic effects were limited on P. glaucum seedlings.

Author Contributions: I.K. generated the data. All authors analysed, examined, and evaluated the data. The manuscript was written by I.K., M.A.R., M.H.B.K., and S.A.A. Statistical analysis was done by I.K. and review was done by H.L. and N.I.R. X.Z. helped in the final revision and editing.

Funding: This research was funded by Modern Agro-industry Technology Research System (CARS-34) and the Sichuan Province Breeding Research grant (2016NYZ0039) and Modern Agricultural Industry System Sichuan Forage Innovation Team.

Acknowledgments: The authors gratefully acknowledge the financial support from the Modern Agro-industry Technology Research System (CARS-34) and the Sichuan Province Breeding Research grant (2016NYZ0039) and Modern Agricultural Industry System Sichuan Forage Innovation Team.

Conflicts of Interest: The authors declare there are no conflicts of interests. 


\section{References}

1. Basavaraj, G.; Rao, P.P.; Bhagavatula, S.; Ahmed, W. Availability and utilization of pearl millet in India. Available online: http://ejournal.icrisat.org/Volume8/IMPI/Availability_and_utilization.pdf (accessed on 26 June 2019).

2. Zhou, S.; Wang, C.; Yin, G.; Zhang, Y.; Shen, X.; Pennerman, K.K.; Zhang, J.; Yan, H.; Zhang, C.; Zhang, X. Phylogenetics and diversity analysis of Pennisetum species using Hemarthria EST-SSR markers. Grassl. Sci. 2019, 65, 13-22. [CrossRef]

3. Badi, S.; Hoseney, R. Use of sorghum and pearl millet flours in cookies. Cereal Chem. 1976, 53, 733-738.

4. Thiombiano, L.; Meshack, M. Scaling up Conservation Agriculture in Africa: Strategies and Approaches; The FAO Subregional Office for Eastern Africa: Kirkos Sub-city, Ethiopia, 2009.

5. Wang, C.; Yan, H.; Li, J.; Zhou, S.; Liu, T.; Zhang, X.; Huang, L. Genome survey sequencing of purple elephant grass (Pennisetum purpureum Schum 'Zise') and identification of its SSR markers. Mol. Breed. 2018, $38,94$. [CrossRef]

6. Hakeem, K.R.; Jawaid, M.; Alothman, O.Y. Agricultural Biomass Based Potential Materials; Springer: Berlin/Heidelberg, Germany, 2015.

7. Austin, L.A.; Mackey, M.A.; Dreaden, E.C.; El-Sayed, M.A. The optical, photothermal, and facile surface chemical properties of gold and silver nanoparticles in biodiagnostics, therapy, and drug delivery. Arch. Toxicol. 2014, 88, 1391-1417. [CrossRef]

8. Majdalawieh, A.; Kanan, M.C.; El-Kadri, O.; Kanan, S.M. Recent advances in gold and silver nanoparticles: Synthesis and applications. J. Nanosci. Nanotechnol. 2014, 14, 4757-4780. [CrossRef] [PubMed]

9. Siripattanakul-Ratpukdi, S.; Fürhacker, M. Issues of silver nanoparticles in engineered environmental treatment systems. Water Air Soil Pollut. 2014, 225, 1939. [CrossRef]

10. Almutairi, Z.M.; Alharbi, A. Effect of silver nanoparticles on seed germination of crop plants. J. Adv. Agric. 2015, 4, 283-288. [CrossRef]

11. Mueller, N.C.; Nowack, B. Exposure modeling of engineered nanoparticles in the environment. Environ. Sci. Technol. 2008, 42, 4447-4453. [CrossRef]

12. Bouwmeester, H.; Dekkers, S.; Noordam, M.Y.; Hagens, W.I.; Bulder, A.S.; De Heer, C.; Ten Voorde, S.E.; Wijnhoven, S.W.; Marvin, H.J.; Sips, A.J. Review of health safety aspects of nanotechnologies in food production. Regul. Toxicol. Pharmacol. 2009, 53, 52-62. [CrossRef]

13. Kaegi, R.; Sinnet, B.; Zuleeg, S.; Hagendorfer, H.; Mueller, E.; Vonbank, R.; Boller, M.; Burkhardt, M. Release of silver nanoparticles from outdoor facades. Environ. Pollut. 2010, 158, 2900-2905. [CrossRef]

14. Tripathi, A.; Liu, S.; Singh, P.K.; Kumar, N.; Pandey, A.C.; Tripathi, D.K.; Chauhan, D.K.; Sahi, S. Differential phytotoxic responses of silver nitrate $\left(\mathrm{AgNO}_{3}\right)$ and silver nanoparticle (AgNps) in Cucumis sativus L. Plant Gene 2017, 11, 255-264. [CrossRef]

15. Yin, L.; Colman, B.P.; McGill, B.M.; Wright, J.P.; Bernhardt, E.S. Effects of silver nanoparticle exposure on germination and early growth of eleven wetland plants. PLoS ONE 2012, 7, e47674. [CrossRef] [PubMed]

16. García-López, J.; Zavala-García, F.; Olivares-Sáenz, E.; Lira-Saldívar, R.; Díaz Barriga-Castro, E.; Ruiz-Torres, N.; Ramos-Cortez, E.; Vázquez-Alvarado, R.; Niño-Medina, G. Zinc Oxide Nanoparticles Boosts Phenolic Compounds and Antioxidant Activity of Capsicum annuum L. during Germination. Agronomy 2018, 8, 215. [CrossRef]

17. Haverkamp, R.; Marshall, A. The mechanism of metal nanoparticle formation in plants: Limits on accumulation. J. Nanoparticle Res. 2009, 11, 1453-1463. [CrossRef]

18. Ejaz, M.; Raja, N.I.; Ahmad, M.S.; Hussain, M.; Iqbal, M. Effect of silver nanoparticles and silver nitrate on growth of rice under biotic stress. IET Nanobiotechnol. 2018, 12, 927-932. [CrossRef] [PubMed]

19. Tripathi, D.K.; Tripathi, A.; Singh, S.; Singh, Y.; Vishwakarma, K.; Yadav, G.; Sharma, S.; Singh, V.K.; Mishra, R.K.; Upadhyay, R. Uptake, accumulation and toxicity of silver nanoparticle in autotrophic plants, and heterotrophic microbes: A concentric review. Front. Microbiol. 2017, 8, 7. [CrossRef] [PubMed]

20. Rahmatpour, S.; Shirvani, M.; Mosaddeghi, M.R.; Nourbakhsh, F.; Bazarganipour, M. Dose-response effects of silver nanoparticles and silver nitrate on microbial and enzyme activities in calcareous soils. Geoderma 2017, 285, 313-322. [CrossRef]

21. Dwivedi, R.; Singh, V.P.; Kumar, J.; Prasad, S.M. Differential physiological and biochemical responses of two Vigna species under enhanced UV-B radiation. J. Radiat. Res. Appl. Sci. 2015, 8, 173-181. [CrossRef] 
22. Lichtenthaler, H.K. biomembranes. In Methods in Enzymology; Elsevier: Amsterdam, The Netherlands, 1987; Volume 148, pp. 350-382.

23. Sagisaka, S. The occurrence of peroxide in a perennial plant, Populus gelrica. Plant Physiol. 1976, 57, 308-309. [CrossRef]

24. Heath, R.L.; Packer, L. Photoperoxidation in isolated chloroplasts: I. Kinetics and stoichiometry of fatty acid peroxidation. Arch. Biochem. Biophys. 1968, 125, 189-198. [CrossRef]

25. Bates, L.S.; Waldren, R.P.; Teare, I. Rapid determination of free proline for water-stress studies. Plant Soil 1973, 39, 205-207. [CrossRef]

26. Ullah, N.; Haq, I.U.; Safdar, N.; Mirza, B. Physiological and biochemical mechanisms of allelopathy mediated by the allelochemical extracts of Phytolacca latbenia (Moq.) H. Walter. Toxicol. Ind. Health 2015, 31, 931-937. [CrossRef] [PubMed]

27. Aebi, H. [3] Catalase in vitro. Methods Enzymol. 1984, 105, 121-126. [PubMed]

28. Chance, B.; Maehly, A. [136] Assay of Catalases and Peroxidases; Elsevier: Amsterdam, The Netherlands, 1955.

29. Klapheck, S.; Zimmer, I.; Cosse, H. Scavenging of hydrogen peroxide in the endosperm of Ricinus communis by ascorbate peroxidase. Plant Cell Physiol. 1990, 31, 1005-1013.

30. Nakano, Y.; Asada, K. Hydrogen peroxide is scavenged by ascorbate-specific peroxidase in spinach chloroplasts. Plant Cell Physiol. 1981, 22, 867-880.

31. Bradford, M.M. A rapid and sensitive method for the quantitation of microgram quantities of protein utilizing the principle of protein-dye binding. Anal. Biochem. 1976, 72, 248-254. [CrossRef]

32. Smith, I.K.; Vierheller, T.L.; Thorne, C.A. Assay of glutathione reductase in crude tissue homogenates using 5, 5'-dithiobis (2-nitrobenzoic acid). Anal. Biochem. 1988, 175, 408-413. [CrossRef]

33. Velioglu, Y.; Mazza, G.; Gao, L.; Oomah, B. Antioxidant activity and total phenolics in selected fruits, vegetables, and grain products. J. Agric. Food Chem. 1998, 46, 4113-4117. [CrossRef]

34. Lopez-Contreras, J.J.; Zavala-Garcia, F.; Urias-Orona, V.; Martinez-Avila, G.C.G.; Rojas, R.; Guillermo, N.-M. Chromatic, phenolic and antioxidant properties of Sorghum bicolor genotypes. Not. Bot. Horti Agrobot. Cluj-Napoca 2015, 43, 366-370.

35. Harris, A.T.; Bali, R. On the formation and extent of uptake of silver nanoparticles by live plants. J. Nanoparticle Res. 2008, 10, 691-695. [CrossRef]

36. Fayez, K.; El-Deeb, B.; Mostafa, N. Toxicity of biosynthetic silver nanoparticles on the growth, cell ultrastructure and physiological activities of barley plant. Acta Physiol. Plant. 2017, 39, 155. [CrossRef]

37. Parveen, A.; Rao, S. Cytotoxicity and genotoxicity of biosynthesized gold and silver nanoparticles on human cancer cell lines. J. Clust. Sci. 2015, 26, 775-788. [CrossRef]

38. Shams, G.; Ranjbar, M.; Amiri, A. Effect of silver nanoparticles on concentration of silver heavy element and growth indexes in cucumber (Cucumis sativus L. negeen). J. Nanoparticle Res. 2013, 15, 1630. [CrossRef]

39. Sarabi, M.; Safipour Afshar, A.; Mahmoodzadeh, H. Physiological Analysis of Silver Nanoparticles and $\mathrm{AgNO}_{3}$ Effect to Brassica napus L. J. Chem. Health Risks 2015, 5, 285-294.

40. Yasur, J.; Rani, P.U. Environmental effects of nanosilver: Impact on castor seed germination, seedling growth, and plant physiology. Environ. Sci. Pollut. Res. 2013, 20, 8636-8648. [CrossRef] [PubMed]

41. Krizkova, S.; Ryant, P.; Krystofova, O.; Adam, V.; Galiova, M.; Beklova, M.; Babula, P.; Kaiser, J.; Novotny, K.; Novotny, J. Multi-instrumental analysis of tissues of sunflower plants treated with silver (I) ions-plants as bioindicators of environmental pollution. Sensors 2008, 8, 445-463. [CrossRef]

42. Pandey, C.; Khan, E.; Mishra, A.; Sardar, M.; Gupta, M. Silver nanoparticles and its effect on seed germination and physiology in Brassica juncea L.(Indian mustard) plant. Adv. Sci. Lett. 2014, 20, 1673-1676. [CrossRef]

43. Sharma, P.; Bhatt, D.; Zaidi, M.; Saradhi, P.P.; Khanna, P.; Arora, S. Silver nanoparticle-mediated enhancement in growth and antioxidant status of Brassica juncea. Appl. Biochem. Biotechnol. 2012, 167, 2225-2233. [CrossRef]

44. Vishwakarma, K.; Upadhyay, N.; Singh, J.; Liu, S.; Singh, V.P.; Prasad, S.M.; Chauhan, D.K.; Tripathi, D.K.; Sharma, S. Differential Phytotoxic Impact of Plant Mediated Silver Nanoparticles (AgNPs) and Silver Nitrate $\left(\mathrm{AgNO}_{3}\right)$ on Brassica sp. Front. Plant Sci. 2017, 8, 1501. [CrossRef]

45. Genty, B.; Harbinson, J.; Briantais, J.-M.; Baker, N.R. The relationship between non-photochemical quenching of chlorophyll fluorescence and the rate of photosystem 2 photochemistry in leaves. Photosynth. Res. 1990, 25, 249-257. [CrossRef] 
46. Jiang, H.S.; Yin, L.Y.; Ren, N.N.; Zhao, S.T.; Li, Z.; Zhi, Y.; Shao, H.; Li, W.; Gontero, B. Silver nanoparticles induced reactive oxygen species via photosynthetic energy transport imbalance in an aquatic plant. Nanotoxicology 2017, 11, 157-167. [CrossRef] [PubMed]

47. Atli, G.; Alptekin, Ö.; Tükel, S.; Canli, M. Response of catalase activity to Ag+, Cd2+, Cr6+, Cu2+ and Zn2+ in five tissues of freshwater fish Oreochromis niloticus. Comp. Biochem. Physiol. Part C Toxicol. Pharmacol. 2006, 143, 218-224. [CrossRef] [PubMed]

48. Mehrian, S.K.; Heidari, R.; Rahmani, F. Effect of silver nanoparticles on free amino acids content and antioxidant defense system of tomato plants. Indian J. Plant Physiol. 2015, 20, 257-263. [CrossRef]

49. Mehta, C.; Srivastava, R.; Arora, S.; Sharma, A. Impact assessment of silver nanoparticles on plant growth and soil bacterial diversity. 3 Biotech 2016, 6, 254.

50. Zancan, S.; Suglia, I.; La Rocca, N.; Ghisi, R. Effects of UV-B radiation on antioxidant parameters of iron-deficient barley plants. Environ. Exp. Bot. 2008, 63, 71-79. [CrossRef]

51. Zhou, S.; Wang, C.; Frazier, T.P.; Yan, H.; Chen, P.; Chen, Z.; Huang, L.; Zhang, X.; Peng, Y.; Ma, X. The first Illumina-based de novo transcriptome analysis and molecular marker development in Napier grass (Pennisetum purpureum). Mol. Breed. 2018, 38, 95. [CrossRef]

52. Cekić, S.; Zlatanović, G.; Cvetković, T.; Petrović, B. Oxidative stress in cataractogenesis. Bosn. J. Basic Med. Sci. 2010, 10, 265. [CrossRef] [PubMed]

53. Krishnaraj, C.; Jagan, E.; Ramachandran, R.; Abirami, S.; Mohan, N.; Kalaichelvan, P. Effect of biologically synthesized silver nanoparticles on Bacopa monnieri (Linn.) Wettst. plant growth metabolism. Process Biochem. 2012, 47, 651-658. [CrossRef]

54. Hegedüs, A.; Erdei, S.; Horváth, G. Comparative studies of $\mathrm{H} 2 \mathrm{O} 2$ detoxifying enzymes in green and greening barley seedlings under cadmium stress. Plant Sci. 2001, 160, 1085-1093. [CrossRef]

55. Wang, L.; Zhu, J.; Wu, Q.; Huang, Y. Effects of Silver Nanoparticles on Seed Germination and Seedling Growth of Radish (Raphanus sativus L.). In Proceedings of the 2nd International Conference on Civil, Materials and Environmental Sciences, London, UK, 13-14 March 2015; Atlantis Press: London, UK, 2015. [CrossRef]

56. Rastogi, A.; Zivcak, M.; Tripathi, D.; Yadav, S.; Kalaji, H.; Brestic, M. Phytotoxic effect of silver nanoparticles in Triticum aestivum: Improper regulation of photosystem I activity as the reason for oxidative damage in the chloroplast. Photosynthetica 2019, 57, 209-216. [CrossRef]

57. Oukarroum, A.; Barhoumi, L.; Pirastru, L.; Dewez, D. Silver nanoparticle toxicity effect on growth and cellular viability of the aquatic plant Lemna gibba. Environ. Toxicol. Chem. 2013, 32, 902-907. [CrossRef] [PubMed]

58. Zou, X.; Li, P.; Huang, Q.; Zhang, H. The different response mechanisms of Wolffia globosa: Light-induced silver nanoparticle toxicity. Aquat. Toxicol. 2016, 176, 97-105. [CrossRef] [PubMed]

59. McShan, D.; Ray, P.C.; Yu, H. Molecular toxicity mechanism of nanosilver. J. Food Drug Anal. 2014, 22, 116-127. [CrossRef] [PubMed]

60. Thuesombat, P.; Hannongbua, S.; Akasit, S.; Chadchawan, S. Effect of silver nanoparticles on rice (Oryza sativa L. cv. KDML 105) seed germination and seedling growth. Ecotoxicol. Environ. Saf. 2014, 104, 302-309. [CrossRef] [PubMed]

61. Mahdavian, K.; Ghorbanli, M.; Kalantari, K.M. The Effects of Ultraviolet Radiation on the Contents of Chlorophyll, Flavonoid, Anthocyanin and Proline in Capsicum annuum L. Turk. J. Bot. 2008, 32, $25-33$.

62. Kishor, P.K.; Sangam, S.; Amrutha, R.; Laxmi, P.S.; Naidu, K.; Rao, K.; Rao, S.; Reddy, K.; Theriappan, P.; Sreenivasulu, N. Regulation of proline biosynthesis, degradation, uptake and transport in higher plants: Its implications in plant growth and abiotic stress tolerance. Curr. Sci. 2005, 88, 424-438.

(C) 2019 by the authors. Licensee MDPI, Basel, Switzerland. This article is an open access article distributed under the terms and conditions of the Creative Commons Attribution (CC BY) license (http://creativecommons.org/licenses/by/4.0/). 